\title{
Introducing Out of School Activities to Fulfil the Need for Physical Activities
}

\author{
Eko Purnomo ${ }^{1,2}$, Amung Ma'mun ${ }^{3}$, Nurlan Kusmaedi ${ }^{4}$, Nina Jermaina ${ }^{5}$, Eddy Marheni ${ }^{6}$ \\ 1 Student of Postgraduate School, Universitas Pendidikan Indonesia, ekopurnomo@upi.edu \\ 2 Sport Science Faculty, Universitas Negeri Padang ekopurnomo@fik.unp.ac.id \\ 3 Universitas Pendidikan Indonesia, amungmamun@upi.edu \\ 4 Universitas Pendidikan Indonesia, nurlankusmaedi@upi.edu \\ 5 Student of Postgraduate School, Universitas Pendidikan Indonesia, ninajermaina@upi.edu \\ 6 Sport Science Faculty, Universitas Negeri Padang eddymarheni@fik.unp.ac.id \\ * Correspondence: Eko Purnomo, email: ekopurnomo@upi.edu ; Tel.: (+62 82376651233)
}

\begin{abstract}
This study aims to introduce out of school activities (OSA) to high school PJOK teachers in Padang Pariaman District, West Sumatra Province, Indonesia. As is known, OSA is an alternative for students in fulfilling their movement needs, especially during the COVID 19 pandemic. Currently, students mostly stay at home, such as studying from home, to doing activities from home. So that there is minimal possibility of carrying out the movement activities recommended by WHO. The research method used is action research. This method gets a problem, then arranges problemsolving, conducts treatment, and finally evaluates. The research results show no teachers who have ever carried out of school activities (OSA); understanding, implementation, and evaluation are also not understood by the teachers. After being given the treatment, the teachers became more aware and understood about out of school activities, starting from understanding, implementing to evaluating what had to be done.
\end{abstract}

Keywords: Out of school activities (OSA) and students' needs for movement.

\section{Introduction}

The problem that discusses out-of-school activities in-school adolescents in the United States and other Western countries shows that, on average, $40-50 \%$ of their actions are not useful to support school activities or activities [1]. This makes it essential for researchers to conduct a study to promote out-of-school activities to reduce the risks associated with the in-active activity [2]. Making out of school activities programs must also pay attention to the students' interests and talents so that the planned schedule can run optimally. Physical literacy in which there are understanding and physical and psychological knowledge which are shared responsibility because these activities are a lifelong benefit of adolescents [3]. Physical activity can still be done during the current COVID 19 pandemic at home (aerobic exercise, bicycle or paddle ergometer, bodyweight sports, dancing, and active video games) for sedentary people (children and adolescents) [4].

How students spend time outside of school can have a big effect on student achievement in the future [5]. Well programmed out of school activities can have long-term (psycho-social and educational) effects on students [6]. Roles in out of school activities that involve multi-components (school, family, and community), have the potential to have a greater impact when compared to simply being carried out separately (individually) [7]. The results of the study explain that the relationship between various elements of society such as health professionals, physical education teachers, and other practitioners in planning, implementing, and evaluating physical activity programs for children has a very big influence. [8]. 
Out of school activities carried out by students do not affect (do not interfere) with homework that must be done [9]; Besides that, out of school activities also have a positive effect on self-confidence and can improve academic ability [10], other benefits, psychologically such as overcoming anxiety and building a personal self which is psychosocial very important for children [3] Activities such as aerobic exercise, bicycle or paddle ergometers, bodyweight training, dancing, and other active games, can still be done at home to help increase immunity resistance as protection from the Covid-19 pandemic. [4]. These findings are consistently about the benefits of doing structured and programmed activities. Out of school activities provide opportunities for children to be able to learn and develop their skills in addition to these skills, doing active activities in sports (in the context of running out of school activities) can improve organizational skills, planning, and time management which are essential for future success. Furthermore, out of school activities may have an influence on the "self-system" [11]. For example, participating in a sports team can increase selfconfidence. That is why we state that out of school activities are positively related to self-confidence while in school [12]. Out of school activities can also have a big impact on quality development such as determination and persistence (selfmotivation) [13].

The findings [14] Out of school activities have a positive relationship with programs at school, besides that, out of school activities can positively facilitate students' abilities. Adolescents who play an active role in out of school activities can build positive relationships with teachers and schoolmates. Therefore it is very important that out of school activities are carried out by students outside of school [9]. Figure 1 presents a theoretical model of the relationship of out of school activities. This model shows that activities outside of school can influence aspects of life directly or indirectly.

Recommendations issued by (Cavill et al.,s 2001; NASPE, n.d.; WHO, 2020) children and adolescents 5-17 years of age should engage in moderate to high-intensity physical activity, at least 60 minutes per day. Due to the COVID-19 learning that was not going well. Students learn more from home then students use more laptops and cellphones which results in students not doing much activity or doing physical activities that have been recommended. Also, the learning that is carried out at school only focuses on the demands and targets of the curriculum. So that the adequacy of the movement activities of students is also still lacking.

In normal circumstances, Physical Education learning is only carried out $2 \times 45$ minutes or 2 hours of lessons every week [18] so it is less than a recommendation to move actively. Moreover, coupled with the COVID 19 pandemic which resulted in students learning more from home. Due to the current COVID 19 pandemic, activities that are usually carried out outside the home must now be carried out at home. such as, studying, playing, working, interacting, or other activities that use online communication a lot [3]. So, it is necessary to understand to apply active physical activity to be an important part, especially for adolescents. 


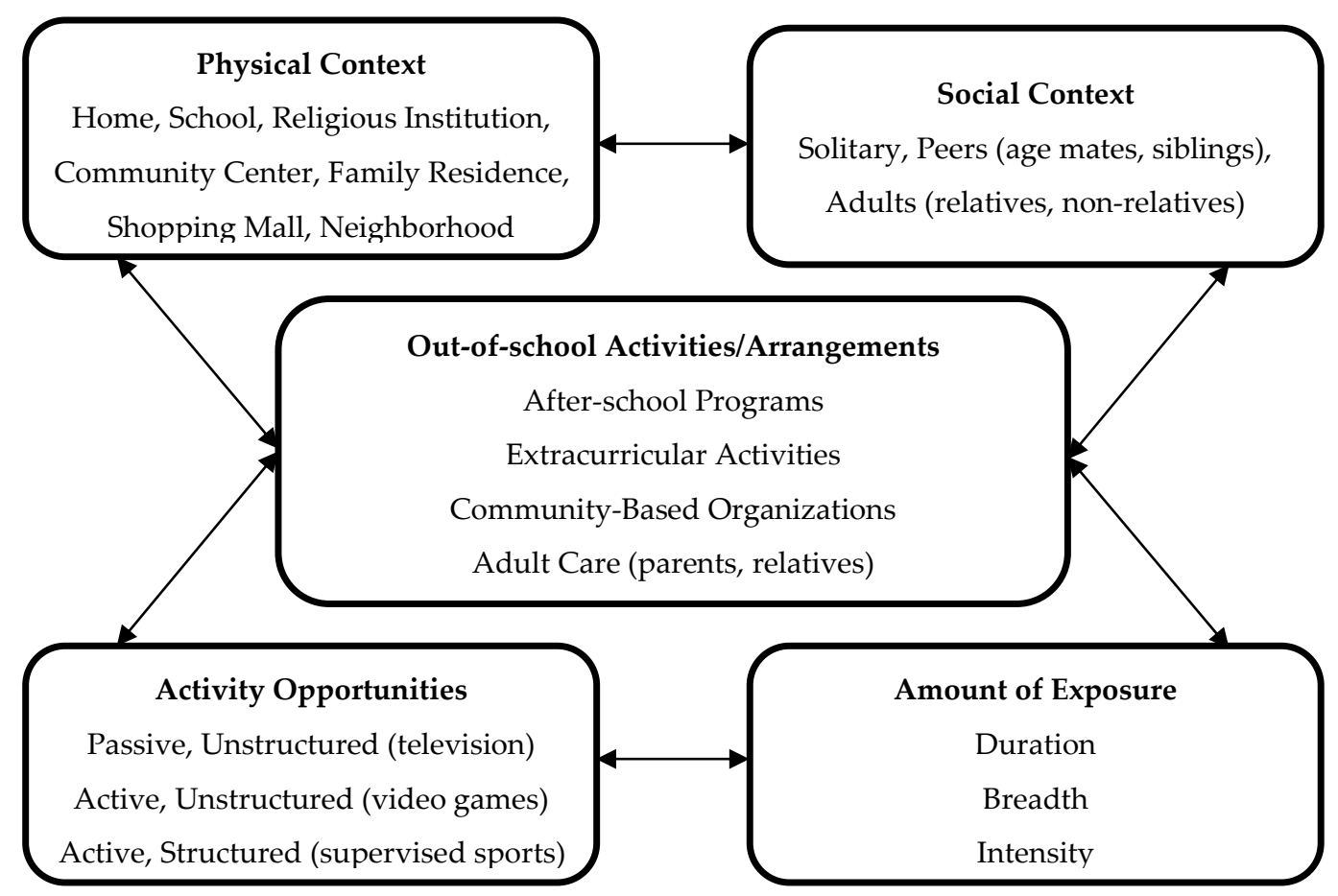

FIGURE 1. The relationship of out of school activities with a physical location, social context and supervision, amount of exposure, activity level, and opportunities for skill-building [2].

\section{Materials and Methods}

\section{Research design}

This study used an action research design. Action research is research to create knowledge and theory while solving problems that occur This action research design is widely used in research or pedagogical studies [19].

\section{Population and sample}

The population was taken from all teachers of PJOK in Padang Pariaman District. The total population is taken or there are 45 teachers. While the sample was taken using a purposive sampling technique, which means that there is a need for sampling. Samples were taken or based on the activeness of the teachers while participating in the activities of the Sports and Health Physical Education (PJOK) MGMP association in Padang Pariaman District. The sample used in this study amounted to 25 teachers. This is because the data provided by the PJOK MGMP organization or association states that teachers are active and always participate in activities every month at the beginning of the month.

\section{Research procedure}

The first thing that researchers do to the samples is to take a questionnaire of willingness to participate in the implementation of the research which will be carried out for one full month. Second, the teachers taken are teachers who are active and affected by COVID 19. Third, at the beginning of the study, the samples consisting of teachers will be given a questionnaire about out of school activities. Including understanding, implementing, and evaluating whether it has been running or not. Fourth, after the results are obtained, the research can be carried out such as giving treatment to teachers. Fifth, teachers are given material about OSA and also how to implement it to get maximum results. Sixth, after completing the implementation of providing material for a predetermined time, the teacher will be given an assessment in the form of filling out a questionnaire and also an assessment of understanding of out of school activities 
learning. Seventh, evaluation is carried out on program implementation. The observation guidelines (pre) in this study contained several rubrics as shown in Table 1.

Table 1. Initial Assessment Rubric for Out of School Activities

\begin{tabular}{|c|c|c|c|c|c|c|c|c|}
\hline \multirow{2}{*}{ No } & \multirow{2}{*}{ Indicator } & \multirow{2}{*}{ Question } & \multicolumn{5}{|c|}{ Qualification } & \multirow{2}{*}{ Score } \\
\hline & & & 1 & 2 & 3 & 4 & 5 & \\
\hline 1 & $\begin{array}{l}\text { Understanding of } \\
\text { out of school } \\
\text { activities }\end{array}$ & $\begin{array}{l}\text { Have you ever heard of out of school activities or } \\
\text { similar activities? } \\
\text { Have you ever learned about the concept of out of } \\
\text { school activities? } \\
\text { Have you ever attended any out of school activities } \\
\text { training in workshops or seminars? }\end{array}$ & & & & & & \\
\hline 2 & $\begin{array}{l}\text { Implementation of } \\
\text { out of school } \\
\text { activities }\end{array}$ & $\begin{array}{l}\text { Have you implemented out of school activities in your } \\
\text { field of study? } \\
\text { Do you know the methods of implementing out of } \\
\text { school activities? } \\
\text { Have you developed the out of school activities that } \\
\text { the students have carried out? }\end{array}$ & & & & & & \\
\hline 3 & $\begin{array}{l}\text { Evaluate out of } \\
\text { school activities }\end{array}$ & $\begin{array}{l}\text { Do you know how to evaluate out of school activities? } \\
\text { Have you evaluated of out of school activities in your } \\
\text { field of study? } \\
\text { How familiar are you with out of school evaluation } \\
\text { activities? }\end{array}$ & & & & & & \\
\hline
\end{tabular}

Table 2. Rubric for Evaluation of the Implementation of Introduction to Out of School Activities

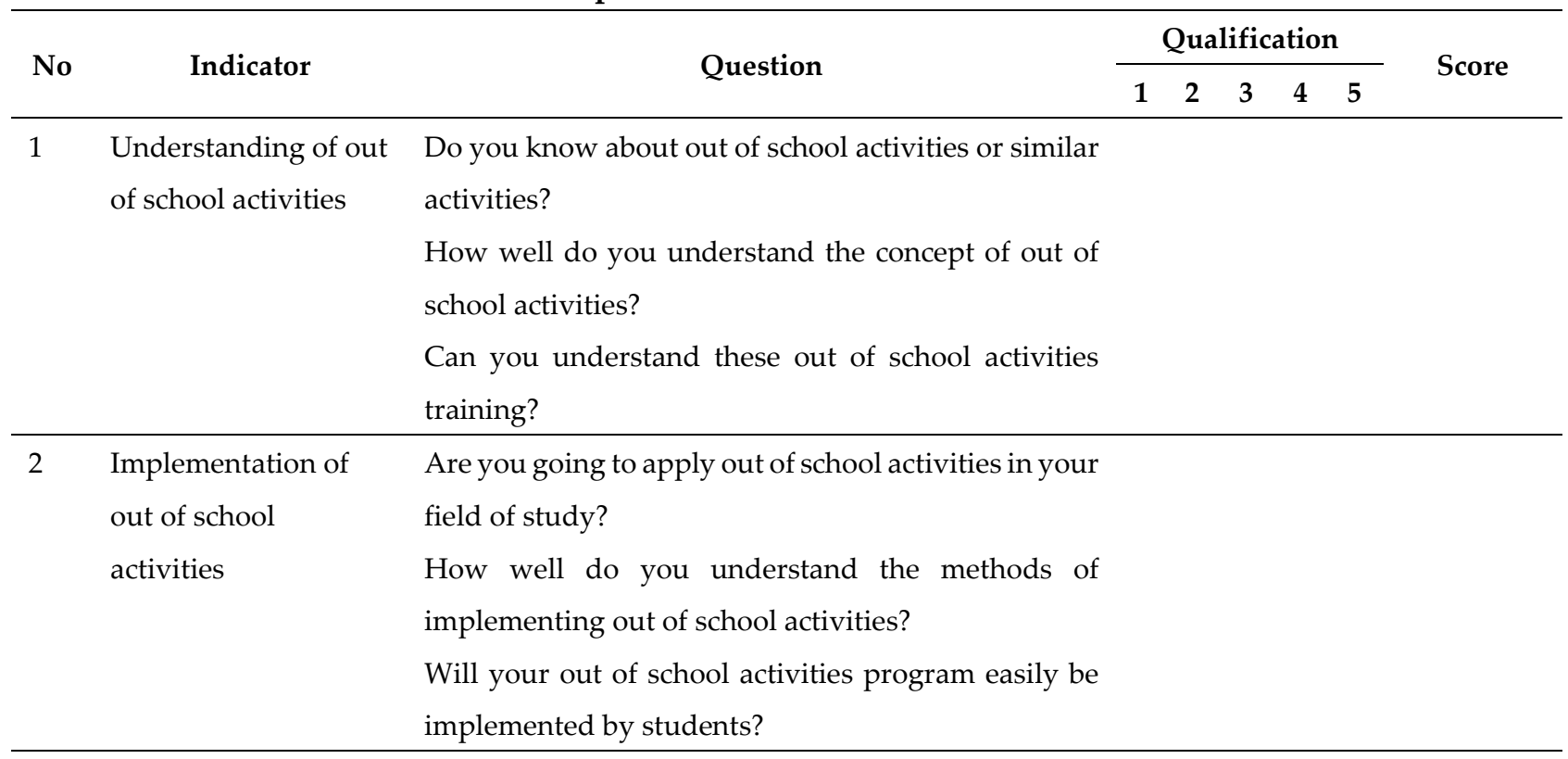

3 Evaluate out of Have you understood how to evaluate out of school school activities activities? 


\begin{tabular}{|c|c|c|c|c|c|c|c|c|}
\hline \multirow{2}{*}{ No } & \multirow{2}{*}{ Indicator } & \multirow{2}{*}{ Question } & \multicolumn{5}{|c|}{ Qualification } & \multirow{2}{*}{ Score } \\
\hline & & & 1 & 2 & 3 & 4 & 5 & \\
\hline & & Do you undertake evaluation out of school activities & & & & & & \\
\hline & & in your field of study? & & & & & & \\
\hline & & How familiar are you with out of school evaluation & & & & & & \\
\hline & & activities? & & & & & & \\
\hline
\end{tabular}

Table 3. Conversion calculation results

\begin{tabular}{lll}
\hline No & Score & Criteria \\
\hline 1 & $91-100$ & Very Good \\
2 & $76-90$ & Good \\
3 & $61-75$ & Fair \\
4 & $51-60$ & Poor \\
5 & $<50$ & Very poor \\
\hline
\end{tabular}

\section{Data analysis technique}

Assessment and evaluation are carried out using a questionnaire created using google form. Furthermore, a questionnaire will be given at the time before and after the implementation of the research. Data processing uses simple statistics, namely percentages. The aim is to determine the level of teacher understanding of the material before and after the training is given. The results of the percentage analysis also make it easier for readers to better understand the meaning and intentions written in this article.

\section{Results}

The test was carried out in 2 stages (pre and post). The first and second stages (pre and post) will assess knowledge, implementation, and evaluation of out of school activities for PJOK high school teachers in Padang Pariaman. The results of the initial survey (pre-test) are shown in Tables 4,5 and 6.

\section{Pre-test}

\section{Table 4. Results of Preliminary Assessment of Understanding Out of School Activities}

\begin{tabular}{lllllcc}
\hline Question & 1 & 2 & 3 & 4 & 5 & Score \\
\hline Have you ever heard of out of school activities or similar activities? & 10 & 5 & 8 & 5 & 0 & 64 \\
Have you ever learned about the concept of out of school activities? & 8 & 6 & 5 & 7 & 2 & 73 \\
Have you ever attended any out of school activities training in workshops or & 4 & 9 & 1 & 10 & 4 & 85 \\
seminars? & & &
\end{tabular}

Table 4 explains that the teacher's ability before the implementation of research related to understanding and knowledge of out of school activities from the score obtained was 222 from the maximum score that could be obtained of 420 or about $52.85 \%$ of the teachers understood understanding and knowledge about out of school activities. It is still classified as "poor" when seen in Table 3 concerning the conversion criteria. The importance of teachers understanding the concept of out of school activities is very important to strengthen their views on how to maintain health by looking for different ways [20]. 
Table 5. Results of the Preliminary Assessment of the Implementation of Out of School Activities

\begin{tabular}{lllllcc}
\hline Question & 1 & 2 & 3 & 4 & 5 & Score \\
\hline Have you implemented out of school activities in your field of study? & 9 & 6 & 5 & 4 & 4 & 72 \\
Do you know the methods of implementing out of school activities? & 8 & 6 & 10 & 2 & 2 & 68 \\
Have you developed the out of school activities that the students have carried out? & 6 & 6 & 7 & 7 & 2 & 77 \\
\hline
\end{tabular}

Table 5 explains that the teacher's ability before the implementation of research related to the implementation of out of school activities from the score obtained was 217 from the maximum score that could be obtained of 420 or about $51.67 \%$ of the teachers understood understanding and knowledge about out of school activities. It is still classified as "poor" when seen in Table 3 concerning the conversion criteria. Because the implementation factor of out of school activities can affect the nature of the classroom activities being taught so that it becomes a key part of the success of a program. Lack of understanding of these factors can become an obstacle in the implementation and development of program out of school activities [21].

Table 6. Results of the Preliminary Assessment of the Evaluation of Out of School Activities

\begin{tabular}{lcccccc}
\hline Question & 1 & 2 & 3 & 4 & 5 & Score \\
\hline Have you figured out how to evaluate out of school activities? & 8 & 7 & 5 & 4 & 4 & 73 \\
Have you evaluated of out of school activities in your field of study? & 6 & 10 & 5 & 5 & 2 & 71 \\
How familiar are you with out of school evaluation activities? & 6 & 6 & 12 & 4 & 70 \\
\hline
\end{tabular}

Evaluation is a systematic procedure to identify the quality, efficacy, and benefits of an object or program in line with defined criteria [22] It is for this reason that teachers understand the final assessment or evaluation of this out of school activities program. In table 6, it can be seen that the teacher's ability before the implementation of research related to the evaluation of out of school activities from the score obtained was 214 from the maximum score that could be obtained of 420 or about $50.59 \%$ of teachers understood understanding and knowledge about out of school activities. It is still classified as "poor" when seen in Table 3 concerning the conversion criteria.

After conducting the initial assessment, it can be seen from the overall results, obtained a score of 653 from the maximum score that can be obtained of 1260 or about $51.83 \%$ of teachers understand the understanding, implementation, and evaluation of out of school activities or with the assessment criteria "poor". Therefore, it is very necessary and possible to carry out treatments or actions to solve existing problems.

\section{Post-Test}

The solution is given by providing training for PJOK teachers at the SMA Padang Pariaman level so that teachers can understand, create and apply out of school activities to support the needs of the student movement, especially during a pandemic like this time. The results of the research after the training activities are carried out, the results can be seen as in Tables 7, 8, and 9.

\section{Table 7. Evaluation Results (Post) Introduction to Understanding Out of School Activities}

\begin{tabular}{|c|c|c|c|c|c|c|}
\hline Question & 1 & 2 & 3 & 4 & 5 & Score \\
\hline Do you know about out of school activities or similar activities? & 3 & 8 & 4 & 6 & 7 & 90 \\
\hline How well do you understand the concept of out of school activities? & 2 & 6 & 5 & 6 & 9 & 98 \\
\hline Can you understand these out of school activities training? & 2 & 4 & 6 & 14 & 2 & 94 \\
\hline
\end{tabular}


In table 7 it can be seen that the ability of the teacher after the implementation of research related to understanding and knowledge of out of school activities from the score obtained was 282 from the maximum score that can be obtained of 420 or about $67.14 \%$ of the teachers understand the understanding and knowledge of out of school activities. This is still classified as "fair" when viewed in Table 3 concerning the conversion criteria. Apart from teachers, parents must also understand about out of school activities, the aim of which is to encourage children to do active activities outside of school hours. [23].

Table 8. Evaluation Results (Post) Introduction to the Implementation of Out of School Activities

\begin{tabular}{|c|c|c|c|c|c|c|}
\hline Question & 1 & 2 & 3 & 4 & 5 & Score \\
\hline Are you going to apply out of school activities in your field of study? & 3 & 4 & 9 & 8 & 4 & 90 \\
\hline How well do you understand the methods of implementing out of school activities? & 4 & 6 & 4 & 5 & 9 & 93 \\
\hline Will your out of school activities program easily be implemented by students? & 3 & 5 & 8 & 4 & 8 & 93 \\
\hline
\end{tabular}

Out-school activities carried out by students in a programmed and well-planned manner, can be beneficial psycho-social and long-term education for adolescents [24]. In table 8, it can be seen that the ability of the teacher before the implementation of research related to the implementation of out of school activities from the score obtained was 276 from the maximum score that can be obtained of 420 or about $65.71 \%$ of teachers understand understanding and knowledge of out of school activities. This is still classified as "fair" when viewed in Table 3 concerning the conversion criteria.

Table 9. Evaluation Results (Post) Introduction to Evaluation of Out of School Activities

\begin{tabular}{|c|c|c|c|c|c|c|}
\hline Question & 1 & 2 & 3 & 4 & 5 & Score \\
\hline Have you understood how to evaluate out of school activities? & 3 & 3 & 12 & 5 & 5 & 90 \\
\hline Do you undertake evaluation out of school activities in your field of study? & 1 & 4 & 4 & 10 & 9 & 106 \\
\hline How familiar are you with out of school evaluation activities? & 2 & 3 & 10 & 7 & 6 & 96 \\
\hline
\end{tabular}

In table 9, it can be seen that the teacher's ability after the implementation of research related to the evaluation of out of school activities, the score obtained was 292 from the maximum score that could be obtained of 420 or about $69.52 \%$ of the teachers understood understanding and knowledge about out of school activities. This is still classified as "fair" when viewed in Table 3 concerning the conversion criteria.

After carrying out the research, it can be seen from the overall results, obtained a score of 850 from the maximum score that can be obtained of 1260 or about $67.46 \%$ of teachers understand the understanding, implementation, and evaluation of out of school activities or with the assessment criteria "fair". In the results of this study, the implementation of the research carried out a change in knowledge and the addition of new knowledge related to out of school activities by PJOK teachers at the high school level of Padang Pariaman District. Figure 2 shows the pre and post-test comparisons in the research that has been carried out. 


\section{FIGURE 2. Comparison of Pre and Post}

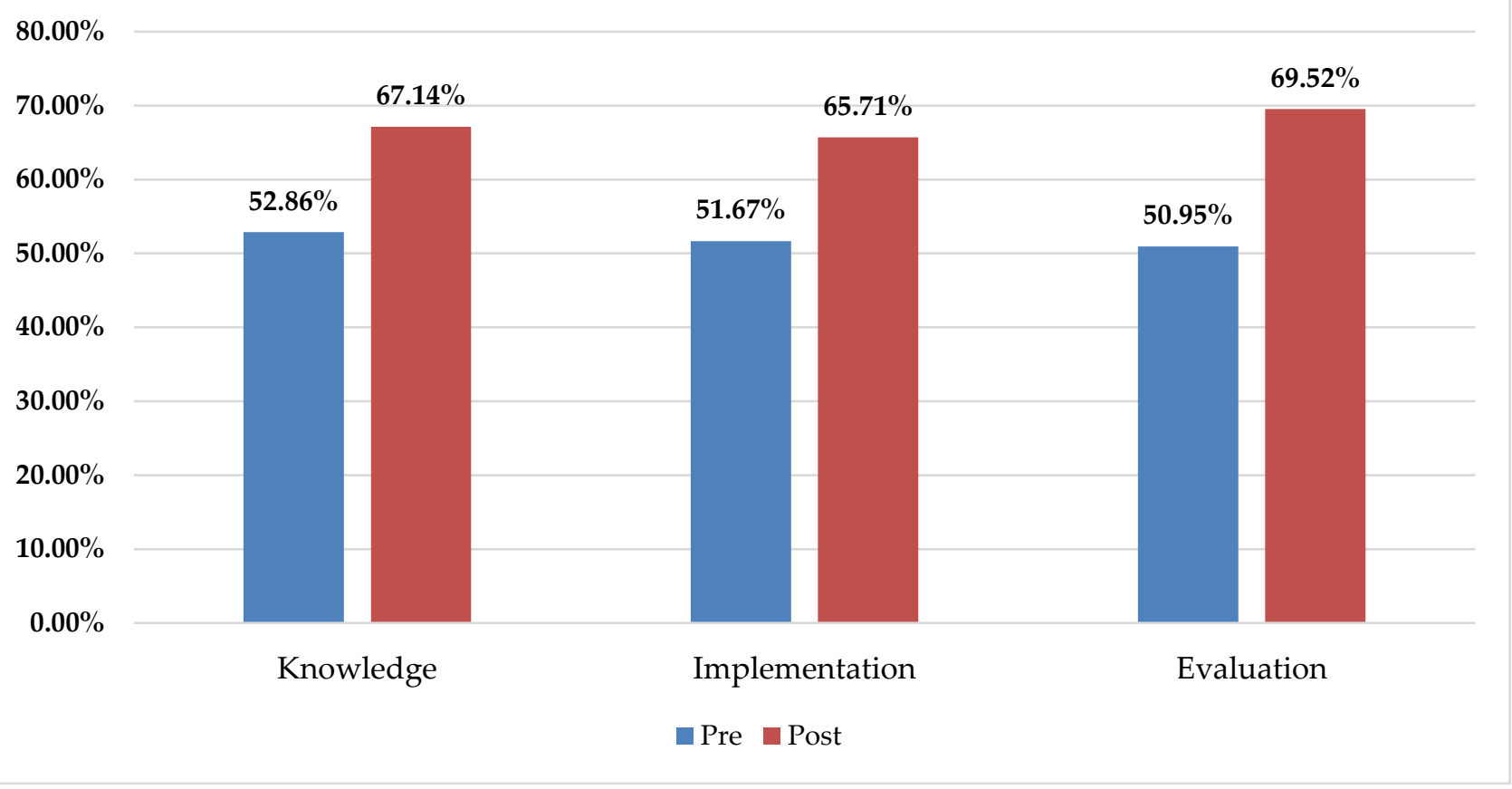

Overall, there was an increase in the results of this study by $15.63 \%$. This is a sufficient result to start and introduce out of school activities to SMA teachers in PJOK in Padang Pariaman District. Out of school activities that are carried out regularly and are well programmed can benefit cognitive abilities and academic abilities. Also, these activities have a major impact on students' physical and mental health. [25]. Until finally, there is high hope that after the implementation of this research, teachers can return to school and then implement out of school activities for their students. Great and intensive support from parents is also needed to support the success of the planned program. The final objective of this research is to socialize, spread out about out of school activities which are organized outside of school activities, and can increase positive development. During the last decade, developed countries have started to implement out of school activities and the results of these activities affect the welfare of children and adolescents [6]. The knowledge possessed by the teacher can later be assigned to students at school, some of the benefits of out of school activities have been explained [4], [10], [22], [26]. Such as skills development, and social relationships provided through involvement in many organized outside school activities.

\section{Conclusion}

1. Learning out of school activities (OSA) has not been implemented by the teachers, some answered that they have implemented OSA learning but are not based on or do not use structured programs or are not carried out properly.

2. Teachers do not yet know the out of school learning activities (OSA) that must be carried out by students to support learning carried out in PJOK in schools.

3. After being given the treatment, the teachers finally realized that learning out of school activities (OSA) was very important and had to be done especially during the COVID 19 pandemic like this.

4. There were an increase and understanding of the material and the application of out of school activities (OSA) for high school teachers PJOK in Padang Pariaman District. 


\section{Suggestion}

1. There needs to be more in-depth research, especially those related to out of school activities as implementation and implementation in schools.

2. Out of school activities must be given special attention by the government and also all people to realize that these activities are very important, especially during the Covid-19 pandemic like today.

3. Out of school activities is one of the ways to overcome activities that currently use more learning and activities through monitor screens.

4. Also, out of school activities are one way to implement WHO recommendations regarding recommendations for physical activity. Besides that, it can also reduce the risk of obesity.

\section{References}

[1] R. W. Larson and S. Verma, "How children and adolescents spend time across the world: Work, play, and developmental opportunities," Psychol. Bull., vol. 125, no. 6, pp. 701-736, 1999, doi: 10.1037/0033-2909.125.6.701.

[2] J. L. Mahoney, D. L. Vandell, S. Simpkins, and N. Zarrett, “Adolescent Out-of-School Activities," Handb. Adolesc. Psychol., no. 2, pp. 228-269, 2009, doi: 10.1002/9780470479193.adlpsy002008.

[3] S. H. Shahidi, J. Stewart Williams, and F. Hassani, "Physical activity during COVID-19 quarantine," Acta Paediatr. Int. J. Paediatr., pp. 2147-2148, 2020, doi: 10.1111/apa.15420.

[4] A. Hammami, B. Harrabi, M. Mohr, and P. Krustrup, "Physical activity and coronavirus disease 2019 (COVID19): specific recommendations for home-based physical training," Manag. Sport Leis., vol. 0, no. 0, pp. 1-6, 2020, doi: 10.1080/23750472.2020.1757494.

[5] B. A. B. \& D. L. D. Jeffrey C. Valentine, Harris Cooper, "Out-of-School Activities and Academic Achievement: The Mediating Role of Self-Beliefs," Educ. Psychol., vol. 37, no. 4, pp. 215-231, 2002, doi: 10.1207/10.1207/S15326985EP3704_4.

[6] R. W. L. Joseph L. Mahoney, Jacquelynne S. Eccles, "Processes of adjustment in organized out-of-school activities: Opportunities and risks," SPRING 2004 C WILEY Period. INC, no. 4, p. 14, 2004, doi: 10.1057/9781137358479_5.

[7] E. M. F. Van Sluijs, A. M. McMinn, and S. J. Griffin, "Effectiveness of interventions to promote physical activity in children and adolescents: Systematic review of controlled trials," Br. J. Sports Med., vol. 42, no. 8, pp. 653-657, 2008, doi: 10.1136/bmj.39320.843947.BE.

[8] L. Cale and J. Harris, "Interventions to promote young people's physical activity: Issues, implications and recommendations for practice," Health Educ. J., vol. 65, no. 4, pp. 320-337, 2006, doi: 10.1177/0017896906069370.

[9] A. M. Dotterer, S. M. McHale, and A. C. Crouter, "Implications of out-of-school activities for school engagement in African American adolescents," J. Youth Adolesc., vol. 36, no. 4, pp. 391-401, 2007, doi: 10.1007/s10964-0069161-3.

[10] C. J. Gidlow, T. Cochrane, R. Davey, and H. Smith, "In-school and out-of-school physical activity in primary and secondary school children," J. Sports Sci., vol. 26, no. 13, pp. 1411-1419, 2008, doi: 10.1080/02640410802277445.

[11] A. Holland and T. Andre, "Participation in Extracurricular Activities in Secondary School: What Is Known, What Needs to Be Known?," Rev. Educ. Res., vol. 57, no. 4, pp. 437-466, 1987, doi: 10.3102/00346543057004437.

[12] S. Afrizal, E. Marheni, M. Ridwan, V. Soniawan, and E. Purnomo, "Pengenalan Physical Fitness di Luar Jam Sekolah Sebagai Upaya Penurunan Kasus Obesitas ( Dampak Corona ' Tetap d i rumah ')," vol. 20, no. 3, pp. 141-148, 2020.

[13] E. Marheni, E. Purnomo, and F. Intan Cahyani, "The Role of Motivation in Increasing Achievement: Perspective Sports Psychology," vol. 7, no. Icssh 2018, pp. 59-62, 2019, doi: 10.2991/icssh-18.2019.14. 
[14] H. W. Marsh, “Extracurricular Activities: Beneficial Extension of the Traditional Curriculum or Subversion of Academic Goals?,” J. Educ. Psychol., vol. 84, no. 4, pp. 553-562, 1992, doi: 10.1037/0022-0663.84.4.553.

[15] WHO, "Recommended levels of physical activity for children aged 5 - 17 years," 2020. https://www.who.int/dietphysicalactivity/factsheet_young_people/en/.

[16] N. Cavill, S. Biddle, and J. F. Sallis, "Health enhancing physical activity for young people: Statement of the United Kingdom expert consensus conference," Pediatr. Exerc. Sci., vol. 13, no. 1, pp. 12-25, 2001, doi: 10.1123/pes.13.1.12.

[17] NASPE, "Physical Activity for Children: A Statement of Guidelines for Children Ages 5-12 (2nd ed.)," NASPE Publ.

[18] Minister of Education and Culture, "Struktur Kurikulum Sekolah Menengah Kejuruan (SMK)/Madrasah Aliyah Kejuruan (MAK)," 2018. [Online]. Available: http://psmk.kemdikbud.go.id/konten/3824/struktur-kurikulumsmk-perdirjen-dikdasmen-no-07dd5kk2018-tanggal-7-juni-2018.

[19] C. Edwards-Groves and S. Kemmis, "Pedagogy, Education and Praxis: understanding new forms of intersubjectivity through action research and practice theory," Educ. Action Res., vol. 24, no. 1, pp. 77-96, 2016, doi: 10.1080/09650792.2015.1076730.

[20] D. A. V. Lamanauskas, "Identifying Pri mary School Teachers ' Health L iteracy," vol. 16, no. 4, pp. 451-466, 2019, doi: 10.36681/tused.2020.0.

[21] D. Cebrián-Robles, A. J. Franco-Mariscal, and Á. Blanco-López, "Preservice elementary science teachers' argumentation competence: impact of a training programme," Instr. Sci., vol. 46, no. 5, pp. 789-817, 2018, doi: 10.1007/s11251-018-9446-4.

[22] S. Berk, "Assessment of Public Schools' Out-of-School Time Academic Support Programs with ParticipantOriented Evaluation," J. Educ. Learn., vol. 7, no. 3, p. 159, 2018, doi: 10.5539/jel.v7n3p159.

[23] B. Tobin, "Understanding the direct involvement of parents in policy development and school activities in a primary school," Int. J. Transform. Res., vol. 4, no. 1, pp. 25-33, 2018, doi: 10.1515/ijtr-2017-0004.

[24] R. W. Mahoney, J. L., Eccles, J. S., \& Larson, "Processes of adjustment in organized out-of-school activities: Opportunities and risks," Manag. Commun. Q., vol. 11, no. 2, pp. 288-309, 2004, doi: 10.1177/0893318997112005.

[25] M. F. Mavilidi et al., "A narrative review of school-based physical activity for enhancing cognition and learning: The importance of relevancy and integration," Front. Psychol., vol. 9, no. OCT, pp. 1-17, 2018, doi: 10.3389/fpsyg.2018.02079.

[26] J. P. Agans and G. J. Geldhof, "Trajectories of Participation in Athletics and Positive Youth Development: The Influence of Sport Type," Appl. Dev. Sci., vol. 16, no. 3, pp. 151-165, 2012, doi: 10.1080/10888691.2012.697792. 